St Antony's / Macmillan Series

General Editors: Archie Brown (1978-85), Rosemary Thorp (1985-92), and Alex Pravda, all Fellows of St Antony's College, Oxford

Recent titles include:

Christopher Abel and Colin M. Lewis (editors)

WELFARE, POVERTY AND DEVELOPMENT IN LATIN AMERICA

Jeremy Adelman (editor)

ESSAYS IN ARGENTINE LABOUR HISTORY, 1870-1930

Orlando Albornoz

EDUCATION AND SOCIETY IN LATIN AMERICA

Amatzia Baram

CULTURE, HISTORY AND IDEOLOGY IN THE FORMATION OF BA'THIST

IRAQ, 1968-89

Archie Brown (editor)

NEW THINKING IN SOVIET POLITICS

Sir Alec Cairncross

PLANNING IN WARTIME

Rodolfo Cerdas-Cruz

THE COMMUNIST INTERNATIONAL IN CENTRAL AMERICA, 1920-36

Anuson Chinvanno

THAILAND'S POLICIES TOWARDS CHINA, 1949-54

Colin Clarke (editor)

SOCIETY AND POLITICS IN THE CARIBBEAN

John Crabtree

PERU UNDER GARCIA

Alex Danchev (editor)

INTERNATIONAL PERSPECTIVES ON THE FALKLANDS CONFLICT

João de Pina-Cabral and John Campbell (editors)

EUROPE OBSERVED

D. R. Dorondo

BAVARIA AND GERMAN FEDERALISM

Michael B. Froman

THE DEVELOPMENT OF THE IDEA OF DETEN IE

Haruhiro Fukui, Peter H. Merkl, Hubertus Müller-Groeling and Akio

Watanabe (editors)

THE POLITICS OF ECONOMIC CHANGE IN POSTWAR JAPAN AND

WEST GERMANY

Heather D. Gibson and Euclid Tsakalotos (editors)

ECONOMIC INTEGRATION AND FINANCIAL LIBERALIZATION

Avner Gil'adi

CHILDREN OF ISLAM 
Beatrice Heuser and Robert $O^{\prime} N$ Neill (editors)

SECURING PEACE IN EUROPE, 1945-62

Derek Hopwood

HABIB BOURGUIBA OF TUNISIA

Hiroshi Ishida

SOCIAL MOBILITY IN CONTEMPORARY JAPAN

Jeremy Jennings (editor)

INTELLECTUALS IN TWENTIETH-CENTURY FRANCE

A. Kemp-Welch

THE BIRTH OF SOLIDARITY

Leslie McLoughlin

IBN SAUD: FOUNDER OF A KINGDOM

Iftikhar H. Malik

US-SOUTH ASIAN RELATIONS, 1940-47

Ziba Moshaver

NUCLEAR WEAPONS PROLIFERATION IN THE INDIAN SUBCONTINENT

Jonathan Osmond

RURAL PROTEST IN THE WEIMAR REPUBLIC

Leslie Palmier

DETENTE IN ASIA?

George Philip

THE PRESIDENCY IN MEXICAN POLITICS

Riitta H. Pittman

THE WRITER'S DIVIDED SELF IN BULGAKOV'S THE MASTER AND

MARGARITA

Gregor Schöllgen

A CONSERVATIVE AGAINST HITLER (translated by Louise Willmot)

Wenguang Shao

CHINA, BRITAIN AND BUSINESSMEN

Pierre L. Siklos

WAR FINANCE, RECONSTRUCTION, HYPERINFLATION AND

STABILIZATION IN HUNGARY, 1938-48

$\mathrm{H}$. Gordon Skilling (editor)

CZECHOSLOVAKIA, 1918-88

Barbara Stallings and Gabriel Székely (editors)

JAPAN, THE UNITED STATES, AND LATIN AMERICA

Joseph S. Szyliowicz

POLITICS, TECHNOLOGY AND DEVELOPMENT

Haris Vlavianos

GREECE, 1941-49: FROM RESISTANCE TO CIVIL WAR

Stephen Welch

THE CONCEPT OF POLITICAL CULTURE 


\section{Frondizi and the Politics of Developmentalism in Argentina, 1955-62}

Celia Szusterman

Senior Lecturer

Faculty of Law, Languages and Communication

University of Westminster

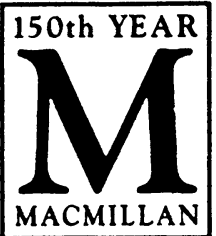


Softcover reprint of the hardcover 1st edition 1993

All rights reserved. No reproduction, copy or transmission of this publication may be made without written permission.

No paragraph of this publication may be reproduced, copied or transmitted save with written permission or in accordance with the provisions of the Copyright, Designs and Patents Act 1988, or under the terms of any licence permitting limited copying issued by the Copyright Licensing Agency, 90 Tottenham Court Road, London WIP 9HE.

Any person who does any unauthorised act in relation to this publication may be liable to criminal prosecution and civil claims for damages.

First published 1993 by THE MACMILLAN PRESS LTD

Houndmills, Basingstoke, Hampshire RG21 2XS

and London

Companies and representatives

throughout the world

ISBN 978-1-349-10518-2 ISBN 978-1-349-10516-8 (eBook)

DOI $10.1007 / 978-1-349-10516-8$

A catalogue record for this book is available from the British Library. 
To my mother and father

in Memoriam

and to Daniel

for the infinite joy he brings to my life 


\section{Contents}

Preface $\quad x$

Acknowledgements xiii

1 The Revolución Libertadora, 1955-58: Liberalism Restored? 1

1. Introduction 1

2. The Decline of the Peronist Regime 3

3. The Revolución Libertadora, 16-21 September 1955: An Account 11

4. The State of the Armed Forces 13

5. General Lonardi and his Foiled 'National Revolution' 16

6. General Aramburu's Objective of a 'Democracy for $\begin{array}{lr}\text { Democrats' } & 19\end{array}$

$\begin{array}{ll}\text { 7. Conclusions } & 30\end{array}$

2 The Split of the Unión Cívica Radical 32

1. Introduction 32

2. A Background of Internal Strife 33

3. The UCR in the 1930s 35

4. The UCR in the 1940s: The Youth Movement and the Intransigencia 38

5. The Intransigencia during the Peronist Decade 44

6. The Internal Structure of the UCR 47

7. The 1956 UCR National Convention in Tucumán 49

8. The UCR Splits - the UCRI is Born 51

3 The Elections for the Constituent Assembly, the Perón-Frondizi Pact and the Failure of the Revolución Libertadora $\quad 54$

1. Introduction 54

2. The Libertadora: 'Caretaker' or 'Revolutionary'? 54

3. Perón in Exile and Peronism in the Resistencia 62

4. The Constituent Assembly, July-November $1957 \quad 64$

5. The Aftermath of the 28 July Elections: the PerónFrondizi Pact $\quad 70$

$\begin{array}{ll}\text { 6. Conclusions } & 73\end{array}$ 
4 The Ideology of Developmentalism and the Development of the Ideology

1. Introduction 75

2. Developmentalism as an Ideology 75

3. The Intellectual Atmosphere in the Aftermath of the Second World War

4. The Premises of Developmentalism 83

5. The Role of the Developmentalist Ideology 89

6. The Electoral Campaign and its Organisation 91

7. Arturo Frondizi - from Radicalism to

Developmentalism

5 The Implementation of the Developmentalist Economic Programme. The First Aim:

'Development'

1. Introduction

2. From 23 February to 1 May $1958 \quad 109$

3. Frondizi's Inaugural Address 111

4. The Cabinet 113

5. A 'Revolutionary' 1958? 116

6. The Stabilisation Plan of 1959-60 120

7. The Evaluation of the Developmentalist Economic Policies

6 The Develpmentalist Strategy: the Internal Constraints. The Second Aim: 'Legality'

1. Introduction

2. Composition of the Legislative Power 131

3. Frondizi and Congress 133

4. Frondizi and the Judiciary 143

5. Conclusions

7 Frondizi's Relations with the Political Parties

1. Frondizi and the UCRI 147

2. Frondizi and the Legal Opposition 164

8 Government and Society: the External Constraints. The Third Aim: 'Social Peace' 168

1. Introduction

2. Developmentalism and Intellectuals 168

3. Developmentalism and Entrepreneurs 176 
4. Developmentalism and Labour 179

5. Developmentalism and the Military 192

9 A Gamble Too Many: The Elections of March 1962 and the Fall of Frondizi 208

1. Introduction 208

2. The 1961 Elections 208

3. The March 1962 Elections 210

4. The Fall 215

$\begin{array}{ll}\text { Epilogue } & 220\end{array}$

$\begin{array}{ll}\text { Notes } & 225\end{array}$

$\begin{array}{ll}\text { Bibliography } & 293\end{array}$

$\begin{array}{ll}\text { Index } & 306\end{array}$ 


\section{Preface}

The last temptation is the greatest treason:

To do the right deed for the wrong reason.

T. S. Eliot's Thomas à Becket

Latin America's poor performance in recent decades was not caused by failing to get policies or prices right, but rather by not getting politics right, in the words of James Dietz and Dilmus James. ${ }^{1}$ It will be my contention that Argentina's predicament has been the result of just such failure, and although I have chosen Frondizi's thwarted government to explore the reasons why this should have been so, I do not believe he was the only, nor the main culprit in an irritatingly long process during which Argentina appeared resolutely to have left a brilliant future behind her. The dilemma facing Argentina was the centuries-old one that so many countries are facing today - how to consolidate a new, democratic republic after a sudden rupture of the old corporatist regime lacking the necessary values and traditions of the desired republic. Perhaps the answer lies in doing what needs to be done rather than by dreaming of what ought to be done. What the Frondizi experience revealed was that the task of institution-building towards the consolidation of a liberal-democratic type of government and society which had been the hope of those who overthrew Peron in 1955 could not be carried out by sheer voluntarism and utilising undemocratic behaviour. The principles of corporatism, State dirigisme and xenophobic nationalism had to be discarded if a free, democratic, and just system could flourish on a sound economic base. With the benefit of hindsight, Frondizi can be regarded as a pioneer in terms of his economic policies. Alas, that was not how his contemporaries judged him.

Argentina in 1958 had not yet learnt the hard lesson of politics, that is to say the contrast between expectations and fulfilment. Finer has noted that 'when a government sets out to be faithful, it is frequently unwise; and when it has learned to be wise, it is frequently unfaithful'. ${ }^{2}$ Frondizi acquired his wisdom just before taking over the presidency, thus his unfaithfulness was more readily seens as duplicitous and, given the passions arisen by Perón and Peronism, treacherous. The developmentalist experiment can be studied under a double focus: (a) as a developmentalist (economic) project, and (b) as a political project, and as such known as integracionismo. The fact that it is remembered as 
developmentalism rather than integrationism reflects the fact that it was relatively more successful in the economic than in the political arena.

The aftermath of Perón's overthrow, including the government resulting from the elections held in 1958, seemed a promising period from the point of view of the revelation of clues to understand Argentina's predicament. Certain elements of a typically Argentine political tradition [and political culture, to use a term in vogue once again] can be traced back to that period (others, to even earlier ones). All in all, I hope this study of the years 1955-62 will contribute to an understanding of the reasons why Argentina only recently appears to have been able to place its future ahead, rather than behind.

When I submitted my thesis in 1986, the Public Records at Kew had just been made available for 1955 . I have been able to consult the records up to and including 1961, and the Washington National Archives on Argentina for the years 1954-59. Regrettably the Foreign Office still sees fit to keep from historical scrutiny some documents that are over 30 years old. It is to be hoped that in the present world context, such secrecy will soon become obsolete.

The fact that 30 years after Frondzi's overthrow the Union Civica Radical - its division in 1956 obliterated as a passing aberration - is still struggling between a populist strand and a more modernising one highlights the difficulty of the task Frondizi faced. It took Alfonsín's victory in 1983 finally to prove to the whole country - and not just the Peronists - that they were not the whole people and thus representatives of the 'interests of the Nation'. The fact that only 30 years after Frondizi's presidency the country as a whole (including the military, business community, labour and politicians) seems to have learnt the harsh lessons of intolerance and ideological fundamentalism (of whichever sign) - and that this required the horror and traumas of thousands of deaths, political, ideological and State terrorism as well as of hyperinflation - exerts a humbling influence when looking at the country's past history. Perhaps all the horror, the pain and the misunderstandings were necessary to achieve that state of maturity Sir John Ward so sadly saw lacking in the whole of South America. A good friend of Argentina, whose despatches were always thorough, always fair, he despondently wrote what many would find insulting even today and yet rings so true. Shortly before leaving his posting he remarked that 'a complete and perfect solution of Argentina's economic problems can however hardly be expected in the foreseeable future, given the prevailing political conditions and the low levels of intelligence, morality and competence which are endemic to South America at this immature 
xii

stage of its development' ${ }^{3}$ At least two of the indictments in the case of Argentina seem to have been overcome.

Celia Szusterman 


\section{Acknowledgements}

My former supervisor at St Antony's and present friend, Alan Angell, was able to remain constant and unfailing in his support and encouragement throughout the years. The editor and the publisher of the present series, Rosemary Thorp and Tim Farmiloe, showed remarkable patience and faith each time a deadline came and went. This book started as a D.Phil thesis at the University of Oxford. My examiners, Sir Raymond Carr and Guido Di Tella, made comments and suggestions that guided me during the process of rewriting.

There are two people to whom I owe a special debt of gratitude. One is Ezequiel Gallo, with whom, in Essex, Oxford, London and Buenos Aires, I have shared for twenty years worries, irritations and hopes in relation to our compatriots. The other is Juan Carlos Torre, who first suggested that the period 1955-58 could provide interesting clues in the understanding of contemporary Argentina. My colleague and good friend generously read several chapters to my great benefit. Throughout the years, be it in Oxford or in Buenos Aires, he patiently and critically read the first chapters offering comments that were consistently thought-provoking. Alas, the Atlantic Ocean made its presence felt, and for the last chapters I was regrettably unable to benefit from Juan Carlos Torre's views.

I owe a special debt of gratitude to those men and women who had supported Frondizi, and shared with me their memories of hopes and disenchantments. I have benefited from their personal recollections. Amongst them, my stepfather, Isak Radunsky and Juan Lozano. Nicolás Babini not only devoted hours to reminisce, but he shared with me his comprehensive collection of cuttings, short-lived publications, etc. My conversations with Ezequiel Gallo, Guido Di Tella, Natalio Botana, Tulio Halperín Donghi, Gustavo Ferrari, Félix Luna, Ernesto Laclau, Ismael Viñas, Ricardo Rojo and Silvia Sigal, in Oxford, London, Buenos Aires and Paris, were invaluable in helping me build a picture and recreate a feeling for the period.

My thanks go to all those protagonists of the events told here, even though not one will be able to share all the views contained herein, who were willing to devote hours to help me. Although I hesitate to pick certain individuals, Roberto Alemann, Alvaro Alsogaray, Rogelio Frigerio, Rodolfo Martínez and Alejandro Agustín Lanusse were especially generous with their time. 
Finally, many friends offered different kinds of support throughout the years. Foremost amongst them, the late Matilde and Manuel Madanes, and Jorge Garfunkel. And my gratitude to all those friends who shared preoccupations, miseries and joys: Malcolm Deas, Ana María Mustapic, Ignacio Klich, and Andrew Graham-Yooll. I am indebted to my colleagues at the University of Westminster: Ana de Otaola, Roger Bell and Hilary Footitt. Deirdre Gallagher spent a whole week at the Public Record Office in Kew photocopying the files for 1961. The Library staff at the School of Languages were always willing and efficient in providing help.

It is customary to thank one's spouse for her/his patience. In my case it is inappropriate to do so: my husband, Tono Masoliver, has none. But he did have something more important to offer, something which helped me enormously through the years: the example of what dedication to, and love for one's work is all about. Without such a companion, the solitary task of book-writing would have been much more difficult to fulfil. 